\title{
DEVELOPMENT OF HVAC SYSTEM FOR MBSL-2 TFRIC BPPT
}

\author{
For the Comfort and Safety of Testing Personnel and the Safety \\ for the Analysis Process and for the Environment from \\ Exposure to SARS-CoV-2 Virus Contamination
}

\author{
Himawan Sutriyanto ${ }^{1}$, Achmad Maswan ${ }^{1}$, Kanon Prabandaru S. ${ }^{1}$, Andhy M. Fathoni ${ }^{1}$ \\ ${ }^{1}$ Laboratory for Thermodynamics, Engines and Propulsion Technology, \\ Agency for the Assessment and Application of Technology \\ e-mail: himawan.sutriyanto@bppt.go.id
}

\begin{abstract}
Tracing, tracking and testing are keys in fighting COVID-19 pandemic. At the start of the pandemic in Indonesia, the capacity to test with RT-PCR methods as the golden standard was still quite low. BPPT, through TFRIC-19, developed MBSL-2 to increase the capacity of Covid-19 PCR Test. This Mobile Bio-Safety Level-2 (MBSL-2) is equipped with HVAC system which has the main function of providing comfort and safety for testing personnel as well as safety for the testing process. This MBSL-2 also provides safety for the environment in which MBSL-2 is placed from contamination of the SARS-CoV2 virus which may be released during the PCR analysis process. There are several variants of the Heating, Ventilating and Air Conditioning (HVAC) MBSL-2 that have been built and operated. The requirement and the design result for MBSL-2 has been discussed in this paper. This HVAC system has to be able to cover cooling load of $2459 \mathrm{~W}$. This MBSL-2 HVAC system has been designed to complement the RT-PCR testing facility that is safe for the personnel, environment and testing result from contamination. This MBSL-2 has been proved to be safe in the operation during this pandemic.
\end{abstract}

Keywords : PCR Test; HVAC; COVID-19; MBSL-2, BSL-2

\section{INTRODUCTION}

The SARS-CoV-2 virus as the cause of the COVID-19 disease has spread throughout the world, which started in Wuhan, China [1] and entered Indonesia with the first patient in early March 2020 [2]. The most dangerous characteristic of this is its very fast transmission, so that by World Health Organization (WHO), COVID-19 is designated as a pandemic disease [3].Since it is a new type of virus that has no vaccine, one of the WHO recommendations to contain the pandemic is to isolate people who are infected so that they do not spread to other people. To overcome the problem of transmission, early detection is needed to find out whether someone is infected or not. One of the most reliable methods is the swab test using Polymerase Chain Reaction (PCR) so that it is called the golden standard of testing for COVID$19[4,5]$.
To overcome the relatively fast problem of COVID-19 transmission, it requires additional testing capacity with PCR in Indonesia. WHO recommends that testing for COVID-19 by PCR requires a laboratory that at least meets the requirements of Biological Safety Level-2 (BSL2), if the lab space has to be isolated from the environment, some additional requirements are needed [10-12]. Based on the need to increase the capacity of the swab examination with PCR and the requirements of the laboratory for testing, Badan Pengkajian dan Penerapan Teknologi or the Agency for the Assessment and Application of Technology(BPPT) developed the Mobile Laboratory Biosafety Level-2 (MBSL-2), a laboratory that meets the requirements of BSL-2 and has been designed to be portable so that its utilization can be maximized. The MBSL-2 first version was designed using standard size containers to speed up manufacture, but also allows it to be 
built using other vehicle platforms such as buses or other vehicles for later versions.

One of the most important components of the MBSL-2 is the HVAC system. In addition to providing comfort for testing personnel, the HVAC system in MBSL-2 also serves to ensure the safety of personnel who work in the lab and also the environment at the lab location so that they are not exposed to viruses that might spread through the HVAC system. This requires a good HVAC system in order to fulfil these tasks.

\section{REVIEW THE MBSL-2 HVAC SYSTEM REQUIREMENTS}

As already stated, WHO recommends a laboratory with a minimum qualification of BSL2 to be used as a testing site for the SARS-CoV2 virus by PCR. However, in the pandemic conditions, additional requirements are needed so that the laboratory does not become a source of virus transmission by requiring that the laboratory must be isolated from the environment. According to the US-NIH Design Requirements Manual (DRM) [6], if the lab space is to be isolated from the environment, the lab space must be in negative pressure and is equipped with a HEPA filter in the exhaust system. Under these conditions, the DRM-NIH requires their BSL-2 microbiology lab HVAC system with the following characteristics:

- Negative lab pressure against the corridors

- Minimum Air change per hour $(\mathrm{ACH})=6$ with $100 \%$ fresh air

- Using an exhaust system equipped with aHEPA filter

- Fan exhaust must have a spare $(\mathrm{N}+1)$

Several other references, mention the recommendations or provisions that apply in each institution or its field regarding the conditions of the lab room to be used. The summary of the recommendations and requirements can be seen in Table 1.

For thermal comfort requirements, the determination of room comfort conditions refers to SNI 03-6572-2001 concerning procedures for designing ventilation systems and air conditioning in buildings [13].

RT-PCR is a sensitive device so it is prone to analysis problems due to contamination. The HVAC system can also play a role in preventing contamination in PCR testing. The methods adopted are installing a HEPA filter on the supply air and providing air flow in the lab in a "one-way" pattern to avoid recirculating air in the lab to prevent air flow from potentially contaminating locations to the test equipment.

Table 1. Requirement for HVAC system in MBSL-2.

\begin{tabular}{|c|c|}
\hline Requirement & Literature [6-12] \\
\hline Air supply & $100 \%$ fresh air [7] \\
\hline Temperature & $\begin{array}{ll}- & 65-72^{\circ} \mathrm{F}(18.3 \\
& \left.-22.2^{\circ} \mathrm{C}\right)[8] \\
- & 21-22^{\circ} \mathrm{C}[9] \\
- & 20-25^{\circ} \mathrm{C}[10] \\
- & \text { Winter: } 69-76^{\circ} \mathrm{F} ; \\
& \text { Summer: } 73-79^{\circ} \\
& \mathrm{F}[7]\end{array}$ \\
\hline \multicolumn{2}{|l|}{ Humidity (RH) } \\
\hline & $\begin{array}{ll}\text { - } & 35-55 \% \text { with a } \\
& \text { recommendation } \\
& \text { of } 45 \%+10 \%[8] \\
\text { - } & 35-50 \%[9] \\
\text { - } & \text { Winter: } 35 \% ; \\
& \text { Summer: } 60 \% \text { [7] }\end{array}$ \\
\hline \multirow{2}{*}{$\begin{array}{l}\text { Air change per } \\
\text { hour }(\mathrm{ACPH})\end{array}$} & \\
\hline & $\begin{array}{ll}\text { - } & 6-15 \mathrm{ACPH} \\
& {[11]} \\
\text { - } & 4-12 \mathrm{ACPH}[9] \\
& 8-12 \mathrm{ACPH} \\
& {[10]} \\
\text { - } & \mathrm{ACH} \text { minimum }= \\
6 \text { at the time the } \\
\text { lab used, and } \\
\mathrm{ACH} \text { minimum = } \\
4 \text { at the time the } \\
\text { lab was not used } \\
\text { or on the outside } \\
\text { of working hours. } \\
\text { [11] }\end{array}$ \\
\hline \multirow[t]{3}{*}{ Room Pressure } & $\begin{array}{l}\text { Minimum } 0.05 \\
\text { "WG with a } \\
\text { recommended } \\
\text { value of: } 0.06 \text { " } \\
\text { WG [8] }\end{array}$ \\
\hline & $\begin{array}{l}-0.1 \text { to } 0.5 \text { in wg } \\
(25 \mathrm{~Pa}-125 \mathrm{~Pa}) \\
{[12]}\end{array}$ \\
\hline & $\begin{array}{l}\text { - } 12.5 \mathrm{~Pa}(0.05 \mathrm{in} \\
\mathrm{wg})[6]\end{array}$ \\
\hline $\begin{array}{l}\text { The speed of air } \\
\text { in the space lab. }\end{array}$ & $\begin{array}{l}50 \mathrm{ft} / \mathrm{min} .(0.254 \mathrm{~m} / \mathrm{sec} .) \\
{[12]}\end{array}$ \\
\hline
\end{tabular}

\section{MBSL-2 HVAC REQUIREMENTS}

Based on the review presented earlier, the MBSL-2 HVAC system requirements were compiled. Following are the requirements and objectives for implementation: 
- For the safety of the personnel working in the lab:

- $100 \%$ fresh air

o $\mathrm{ACH}>6 \mathrm{ACPH}$

- Use Anteroom

- Air flow is regulated "unidirectional" without recirculation (depending on equipment placement)

- For environmental safety:

- Negative pressure of the lab

- Exhaust HEPA filter

- Redundant exhaust fan

- For tester's convenience:

o Temperature: 18 to $25^{\circ} \mathrm{C}$

o $\mathrm{RH}: 35 \%-65 \%$

- For the safety of the test results:

- Supply air HEPA filter

o Air flow is regulated "unidirectional"

Based on these requirements, when compared to the BSL-2 requirements there are differences as shown in Table 2.

Table 2. Comparison between MBSL-2and BSL-2 HVAC system requirements

\begin{tabular}{|c|c|c|c|c|}
\hline & \multicolumn{3}{|c|}{ Biosafety Level } & MBSL- \\
\hline & 1 & 2 & 3 & 4 \\
\hline $\begin{array}{l}\text { Isolation of } \\
\text { laboratory }\end{array}$ & No & No & Yes & \\
\hline $\begin{array}{l}\text { Room sealable } \\
\text { for } \\
\text { decontamination }\end{array}$ & No & No & Yes & \\
\hline $\begin{array}{l}\text { Ventilation: } \\
\text { - Inward } \\
\text { airflow }\end{array}$ & No & Desirable & Yes & Yes \\
\hline $\begin{array}{l}\text { - Controlled } \\
\text { ventilation } \\
\text { system }\end{array}$ & No & Desirable & Yes & Yes \\
\hline $\begin{array}{l}\text { - HEPA- } \\
\text { filtered air } \\
\text { exhaust }\end{array}$ & No & No & Yes/No & Yes \\
\hline $\begin{array}{l}\text { Double door } \\
\text { entry }\end{array}$ & No & No & Yes & No \\
\hline Airlock & No & No & No & No \\
\hline $\begin{array}{l}\text { Airlock with } \\
\text { shower }\end{array}$ & No & No & No & No \\
\hline Anteroom & No & No & Yes & Yes \\
\hline $\begin{array}{l}\text { Anteroom with } \\
\text { shower }\end{array}$ & No & No & Yes/No & No \\
\hline $\begin{array}{l}\text { Effluent } \\
\text { treatment }\end{array}$ & No & No & Yes/No & \\
\hline
\end{tabular}

\section{MBSL-2 HVAC SYSTEM DESIGN}

To speed up the design and fabrication process, the lab is planned to be built using a standard $20 \mathrm{ft}$ long container. For the needs of the HVAC system, the lab wall uses heat insulating material which also meets the requirements for the biology lab wall.

The results of the cooling load calculation produce the following cooling loads:

- Lab room: $1336 \mathrm{~W}$,

- Equipment: $1123 \mathrm{~W}$,

- Total: $2459 \mathrm{~W}$.

To determine the capacity of the AC unit, it is assumed that the environmental conditions are as follows:

- Air dry-bulb temperature: $35^{\circ} \mathrm{C}$,

- $\mathrm{RH}: 80 \%$.

While the target room conditions are:

- Room temperature: $22^{\circ} \mathrm{C}$,

- $\mathrm{RH}: 40 \%$.

The calculations that have been carried out under these conditions, produce an estimate of $\mathrm{ACH}=19.83$ and the minimum cooling capacity required for the $A C$ unit: $15.59 \mathrm{~kW}$ (equivalent to an AC unit with a capacity of approximately $5.9 \mathrm{pk})$.

The MBSL-2 HVAC system is also designed to include the following features:

- Positive anteroom pressures and negative laboratory room pressures are regulated by damper openings and fan exhaust inverters.

- $\mathrm{ACH}>6$ is regulated by the damper opening and fan booster inverter.

- The room temperature is regulated from the $\mathrm{AC}$ machine, equipped with a heater to reduce $\mathrm{RH}$.

- Exhaust air is filtered by HEPA filter $\mathrm{H} 14$, and supply air by medium-filter and HEPA filter H13.

- A redundant fan exhaust is provided, so that if the operating fan experiences a failure, the back-up fan will operate to maintain operating conditions without changing the flow pattern in the lab.

\section{PROGRAM RESULTS}

The as built drawings of the MBSL-2 HVAC system are as shown in Figure 1. 


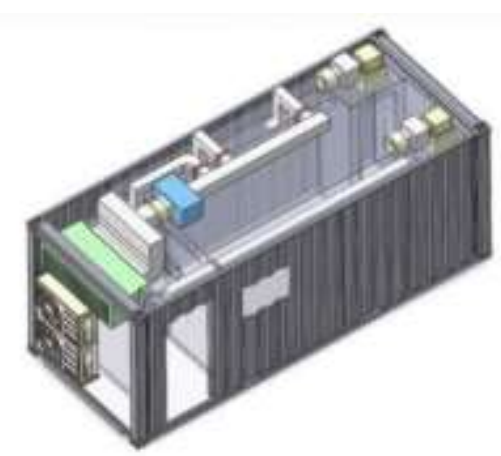

1.a

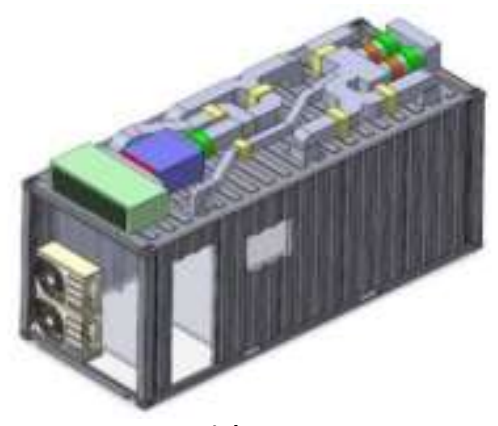

1.b

Figure 1. System HVAC in MBSL-2 version \#1 (a) and version \#2 (b).

Apart from versions \#1 and \#2 which are MBSL-2 with a 20ft length container platform, actually there are also other MBSL-2 designs with a bus platform. However, it is now still in the process of development and will be reported in a subsequent paper.

Version \#1 was fixed to version \#2 to ensurethat in the event of a failure of the exhaust fan causing the operation of the backup fan, it did not cause a change in the airflow pattern in the lab room.

The MBSL-2 HVAC system can be monitored in BAS as shown in the BAS display image shown in Figure 2. The figures are the BAS displays for version \#1 system.

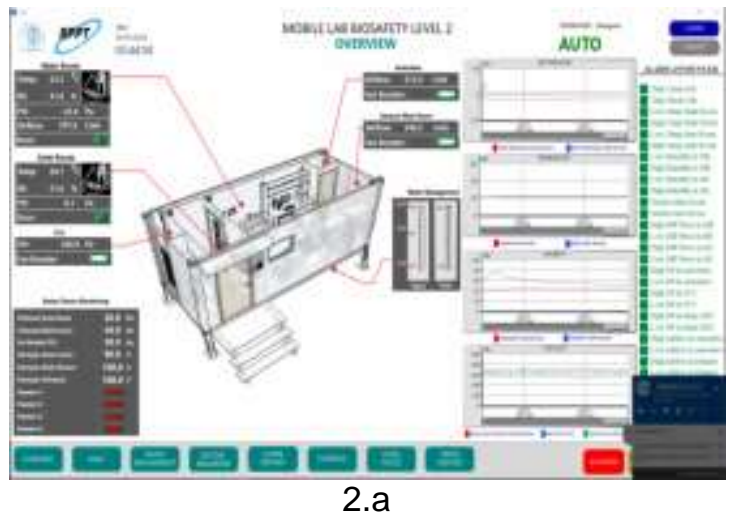

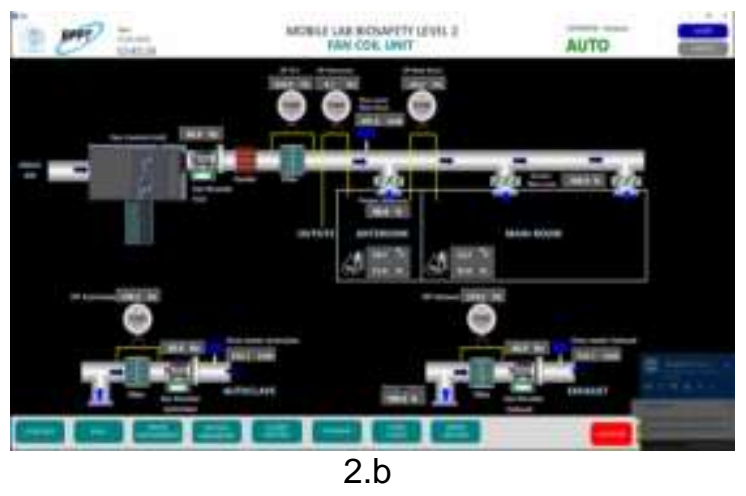

Figure 2. Display of HVAC system version \#1 on BAS monitor.

\section{CONCLUSION}

The requirement and the design result for MBSL-2 has been discussed in this paper. This HVAC system has to be able to cover cooling load of 2459 W. This MBSL-2 HVAC system has been designed to complement the RT-PCR testing facility that is safe for the personnel, environment and testing result from contamination. This MBSL-2 has been proved to be safe in the operation during this pandemic. The HVAC system for the MBSL-2 TFRIC BPPT has been designed, manufactured and operated to provide comfort and safety functions for personnel, as well as safety for PCR test results and for the laboratory environment from SARS-COV-2 virus contamination.

\section{AUTHOR INFORMATION}

\section{Corresponding Author}

Email: himawan.sutriyanto@bppt.go.id. Phone: (021) 7560539

\section{Author Contributions}

Himawan Sutriyanto is the main designer/engineering leader of the MBSL-2 HVAC system and main writer of the paper. Achmad Maswan contributed in the calculation of the cooling load and system calculation. Kanon Prabandaru contributed on the engineering drawing and configuration. Andhy M. Fathoni contributed on the part of design requirement and finishing/revising the paper. 


\section{ACKNOWLEDGMENTS}

Thanks to TFRIC-19 BPPT for assigning and sponsoring this MBSL-2 development activity. Thanks also to the rest of the MBSL-2 team, especially the BAS and electrical teams who contributed to the HVAC operation control system and supply of power.

\section{REFERENCES}

[1] D. Wang, B. Hu, C. Hu, et al. "Clinical characteristics of 138 hospitalized patients with 2019 Novel Coronavirus-infected pneumonia in Wuhan, China", JAMA, 2020, pp. 1061-1069. DOI:10.1001/jama.2020.1585.

[2] R. Hidayat, N. Aini, A.F.N. Ilmi, F. Azzahroh, and A. Giantini, "Test, trace, and treatment strategy to control COVID19 infection among hospital staff in a COVID-19 referral hospital in Indonesia", Acta medica Indonesiana-the Indonesian Journal of Internal Medicine, Vol. 52, 2020, pp.206-213.

[3] WHO, "WHO Coronavirus Disease (COVID-19) dashboard", 2020, Available from: https://covid19.who.int/

[4] Scottish Government, "Covid-19 - Test, trace, isolate, support: A public health approach to maintaining low levels of community transmission of COVID-19 in Scotland", 2020.

[5] A. J. Kucharski, P. Klepac, A.J.K. Conlan, et al., "Effectiveness of isolation, testing, contact tracing, and physical distancing on reducing transmission of SARS-CoV-2 in different settings: a mathematical modelling study", Lancet Infectious Disease, 2020.

[6] National Institute of Health (NIH), "Technical resources-design requirements manual", Office of Research Facilities, 2020.
[7] Stanford University, "General: ventilation consideration", cited: March 2021, Available from:https://ehs.stanford.edu/manual/labo ratory-standard-designguidelines/general-ventilationconsiderations.

[8] J. DeLaurentis, K. Biopharm, "Designing HVAC systems for biosafety level requirements", cited: March 2021, Available

from:https://www.pharmaceuticalonline.co $\mathrm{m} /$ doc/designing-hvac-systems-forbiosafety-level-re-0001.

[9] ASHRAE, I. B. D. McIntosh, C. B. Dorgan, and C. E. Dorgan, "Ashrae laboratory design guide - Planning and operation of laboratory HVAC systems", American society of heating, refrigerating and air conditioning engineers (ASHRAE), 2002.

[10] US Food and Drug Administration, "Ora Lab Manual Volume II", Available from:https://www.fda.gov/scienceresearch/field-science-andlaboratories/field-science-laboratorymanual.

[11] Siemens Industry, "Laboratory ventilation codes and standards", 2013. Available from:https://www.downloads.siemens.com /downloadcenter/Download.aspx?pos=download\&fct $=$ getasset $\&$ id $1=$ A6V 10324363

[12] ANSI, "Laboratory ventilation (ANSI / AIHA Z9.5 -2012)", The American society of safety engineers (ASSE), 2012.

[13] Litbang PU, "Tata cara perancangan sistem ventilasi dan pengkondisian udara pada bangunan gedung", Standard Nasional Indonesia (SNI), 2001. 